\title{
THERAPEUTIC EFFECTS OF CARBONATED MINERAL WATERS IN CARDIOVASCULAR REHABILITATION
}

\author{
Dogaru Gabriela12, Radulescu Alexandru \\ 1. "Iuliu Hatieganu" University of Medicine and Pharmacy Cluj-Napoca \\ 2. Clinical Rehabilitation Hospital Cluj-Napoca
}

\begin{abstract}
Carbonated water baths represent a method used for the prevention and treatment of cardiovascular diseases in some spa resorts in Romania. Carbonated mineral waters are the result of the filtration of depth waters through volcanic soils that contain carbon dioxide. The most important effect is the direct effect of carbon dioxide, which is absorbed through the skin, with an absorption coefficient of $30-35 \mathrm{ml} / \mathrm{min} / \mathrm{sqm}$ body surface area. An excitation of vascular receptors and a dilation of dermal papillae, responsible for skin erythema, occur. The effects of the carbonated water bath on the cardiovascular system are the following: decrease of peripheral resistance by the direct action of carbon dioxide on arterioles and arteriovenous anastomoses; increase of both systolic and diastolic cardiac output, not by central mechanism as in the case of hot baths, but initially, by passive peripheral vasodilation, without increased venous return; subsequently, by accumulation in the cutaneous venous system, venous return towards the right heart will be increased, with a higher diastolic filling and a higher stroke volume. Carbonated water baths increase arteriolar blood flow in the skin, the vasodilator effect being directly proportional to the carbon dioxide concentration in the mineral bath. The effect of external carbonated water treatment is based on mechanical and thermal action, as well as on the chemical properties of carbon dioxide, its influence being either local or postabsorptive. Carbonated water baths are a therapeutic method that is also used in the treatment facilities of the Baile Tusnad spa resort, under the supervision of qualified medical experts, in a pleasant environment close to nature.
\end{abstract}

Key words: carbonated mineral waters, cardiovascular diseases, carbon dioxide

Balneotherapy is a treatment method that uses natural therapeutic factors with well researched and recognized healing properties, based on chemical, mechanical and thermal effects on the organism.

Carbonated water baths are a method used for the prevention and treatment of cardiovascular diseases, in some spa resorts in Romania.

Carbonated mineral waters contain a wide variety of chemical elements extracted from the rocks through which they have infiltrated. Mineral salt molecules are dissociated into ions and only part of them remain undissociated, the physical system in cause being formed by a dispensing environment, water, and a disperse phase, ions or molecules.

Mineral water is a real "optically empty" solution, particles having sizes smaller than a millimicron.

Carbonated mineral waters are the result of the filtration of depth waters through volcanic soils that contain carbon dioxide. The carbon dioxide obtained in this way will favor the dissolution of other elements contained in the soil layers through which water passes: calcium, magnesium, sodium, iron, chloride, bromide, so that finally, carbonated mineral waters will have a complex composition [1]. 
The therapeutic effects of carbonated water baths are based on the action of carbon dioxide and less on the pharmacodynamic action of mineral salts in the composition of mineral water. The temperatures used for carbonated water baths are situated below the value of $34^{\circ} \mathrm{C}$, below the point of thermal indifference of the water, being hypothermic baths [1]. The dissolved carbonic acid contains carbon dioxide (CO2) and, in addition, free $\mathrm{CO} 2$ bubble suspension [2]. In the carbonated water bath, the skin undergoes an excitation resulting from the simultaneous, continuously moving contrast between the aqueous and the gas phase in the mineral bath. The skin surface is covered with small gas bubbles, which are extremely fine in the case of carbonated water baths; when they have reached a certain size, these bubbles detach, being replaced by other vesicles, through the mechanical collision effect [1].

Gas bubbles are uniformly distributed on the skin surface, forming a fine $0.5 \mathrm{~mm}$ thick film adherent to the skin, which plays a thermal insulation role, inducing micromassage and microexplosions, with the stimulation of tactile receptors. The thermal gradient is $1.5^{\circ}$.

The most important effect is the direct effect of $\mathrm{CO} 2$, which is absorbed through the skin, with an absorption coefficient of $30-35 \mathrm{ml} / \mathrm{min} / \mathrm{sqm}$ body surface area [2].

An excitation of vascular receptors and a dilation of dermal papillae, responsible for skin erythema, occur [2].

Water and carbon dioxide have different thermal conductivity values, so that in a bath of $28-32^{\circ} \mathrm{C}$, the skin areas in contact with the aqueous phase are below the point of thermal indifference, while those in contact with the gas phase have exceeded this point. Thus, simultaneous cold and hot stimuli are triggered, and the surfaces in contact with the thermal receptors of the skin continuously change throughout the duration of the mineral bath.

Following the summation of excitations in space and time, evidenced by electrophysiological studies, the carbonated water bath reduces the sensitivity of cold receptors (Kraus) and increases the sensitivity of hot receptors (Ruffini).

The carbonated water bath increases arteriolar blood flow in the skin, which is demonstrated with the fluvograph, the vasodilator effect being directly proportional to the carbon dioxide concentration in the mineral bath. Carbon dioxide is absorbed through the skin even in the absence of gas bubbles [1]. There is a vasodilation of arterioles and arteriovenous anastomoses. The temperature of the carbonated water bath is between $28-31^{\circ} \mathrm{C}$ [2].

This explains the sensation of heat in the carbonated water bath, although the water temperature is below the point of thermal indifference. As a result, there is also a hypothermic effect on the organism, which explains some favorable effects on the circulatory system.

The effect of external carbonated water treatment is based both on mechanical and thermal action, as well as on the chemical properties of carbon dioxide, its influence being either local or postabsorptive [1].

Studies performed in Vatra Dornei evidenced the following in hypertensive patients with atherosclerosis: an improvement of peripheral circulation and the normalization of vascular hyperreactivity, explored by the Hines test, an improvement of collateral circulation and of the claudication index, evaluated by radioisotopic and clinical methods, the reduction of blood pressure values. 
Clinico-functional improvements were accompanied by a normalization of the biochemical syndrome, i.e. reduction of fibrinemia, reduction of the prothrombin time, decrease of plasma free fatty acid concentration, reduction of lipemia, intensification of cholesterol catabolism and improvement of dyslipidemia [1].

Recent studies carried out in the Buzias spa resort certify the favorable effects of external carbonated water treatment in stage 2 arterial hypertension [1].

An extensive study conducted in Covasna on 1000 hypertensive patients demonstrated the hypotensive effect and capillary vasodilation evaluated by capillaroscopy. In peripheral ischemic disorders, an improvement of the claudication index and oscillometric values was reported [1].

A study on weather sensitivity in patients with predominantly coronary or peripheral atherosclerosis, treated in addition to trapezoidal currents by carbonated water baths, obtained the following results: the weather sensitivity of the patients in relation to the passage of cold atmospheric fronts decreased at the end of treatment, there was a tendency of vegetative reactions towards sympathicotonia with the exacerbation of clinical symptomatology, coronary patients had a higher weather sensitivity than patients with peripheral ischemia, expressed by angina pectoris episodes, particularly on the day of passage of atmospheric masses [3].

Carbonated water baths have the following effects on the cardiovascular system:

1. Decrease of peripheral resistance by the direct action of $\mathrm{CO} 2$ on arterioles and arteriovenous anastomoses

2. Increase of both systolic and diastolic cardiac output, not by central mechanism as in the case of hot baths, but initially, by passive peripheral vasodilation, without increased venous return; subsequently, by accumulation in the cutaneous venous system, venous return towards the right heart will be increased, with a higher diastolic filling and a higher stroke volume

Blood pressure is not significantly changed compared to hot baths, where the decrease is much higher. There is a tendency of increasing systolic blood pressure and decreasing diastolic blood pressure. An economical cardiac activity occurs by the increase of venous return and the elimination of central stimulation that would increase the heart rate. Carbonated water baths prolong the diastole by increasing venous return, an action that according to some authors is comparable to digitalization.

The duration of a bath is 20-30 minutes. Frequency: 1 session every day or every 2 days. Carbonated water baths are indicated along with special diet regimes and drug treatment in the following cardiovascular diseases: stage 1 and 2 arterial hypertension under therapeutic control; secondary arterial hypertension without signs of kidney failure; chronic ischemic heart disease, sequelae of myocardial infarction, at least 3 months after the acute episode; operated valvular heart disease without significant clinical and hemodynamic disorders, at least 3 months after surgery; compensated aortic/mitral insufficiency; peripheral arteriopathies: stage 1 and 2 chronic peripheral obliterating arteriopathy, Buerger thromboangiitis, peripheral circulatory disorders; chronic venous diseases: conditions after superficial thrombophlebitis, at least 1 month after the acute phase, conditions after deep thrombophlebitis, at least 6 months after the acute phase, operated varices, at least 3 months after surgery [4].

There are also specific contraindications: myocardial infarction 
with complication and severe evolution in the acute phase; non-painful ischemic heart disease with severe rhythm and conduction disorders or with heart failure; recent thromboembolic accidents; heart failure; cerebral atherosclerosis with mental disorders; thrombotic cerebral accidents with important neurological sequelae; decompensated renal diseases; water-electrolyte metabolic disorders [4]. Carbonated water baths are also used as a therapeutic method in the treatment facilities of the Baile Tusnad spa resort, under the supervision of qualified medical experts, in a pleasant environment close to nature (springs no. 1 and no. 2).

The Baile Tusnad spa resort is situated on the left bank of the Olt river (at $32 \mathrm{~km}$ from Miercurea Ciuc, $37 \mathrm{~km}$ from Sfantu Gheorghe, and $67 \mathrm{~km}$ from Brasov). It has an intramountain depression climate, with a mean annual temperature of $6^{\circ} \mathrm{C}[6]$.

The beneficial effects of the Baile Tusnad curative waters are well known; these are recommended for the treatment of a number of diseases such as cardiovascular, digestive, nervous system or endocrine disorders [6].

This region became known after the miraculous healing of a shepherd's son, which drew attention to the curative waters found in the proximity. It is considered that the Baile Tusnad spa resort was founded in the same period, namely in 1842. It is also in 1842 that mineral water bottling was initiated and subsequently, the discovery of mesothermal waters and mofettes marked the beginning of the development of this spa resort. Thus, a number of villas, a casino, treatment facilities, as well as parks were built in the area [5].

The existence of the mineral springs with curative effects in the Baile Tusnad area was documented as early as the 18th century. The resort was destroyed during the revolution of 1849 , then it was rebuilt, and in 1861 it became known as Baile Tusnad; in 1968, by Decision of the Council of Ministers, Baile Tusnad became a town.

The Baile Tusnad resort has 44 natural springs and wells, and the springs that are used include the following: Apor, Mikes, Ileana and Stanescu springs.

Baile Tusnad is also called the "Pearl of Transylvania", being one of the most beautiful spa resorts in Romania, with highly ozonated air rich in aerosols and negative ions, having a subalpine climate, with cold winters [6].

Lake Sfanta Ana, the only lake of volcanic origin in Romania, is situated at a $946 \mathrm{~m}$ altitude, in the Ciomatu massif, at about $25 \mathrm{~km}$ from the Baile Tusnad resort. Lake Sfanta Ana lies at the bottom of an extinct volcano (Ciomatu), in the Puciosu mountains, its waters being derived exclusively from rain and melting snow. In the proximity of the lake, there is a Catholic chapel whose patron is Saint Anne, which is visited by a great number of believers every year. This lake is unique in Central and Eastern Europe.

\section{References}

1. Munteanu Constantin. Ape minerale terapeutice, Editura Balneara Bucuresti, 2013

2. Zdrenghea D, Branea I. Recuperarea bolnavilor cardiovasculari, Editura Clusium, Cluj Napoca, 1995

3. Studii si cercetari de balneologie si fizioterapie, Ministerul sanatatii si Prevederilor sociale. Institutul de Balneologie si Fizioterapie, Editura Medicala, Bucuresti, 1964

4. Cura Balneoclimatică - indicaţii şi contraindicații. Ministerul Sanatatii, Editura Medicala, Bucuresti, 1986.

5. Dorgo, CI. Transilvania, un El Dorado balnear? Editura Ansid, 2003

6. Teleki, N, Munteanu, L. Romania Balneo-Turistica, Editura Royal Company, 2012. 